TRIDARMA: Pengabdian Kepada Masyarakat (PkM), 5 (1) (2021) o1-09

\title{
Edukasi Pemanfaatan Aplikasi Marketplace Dalam Menunjang Kegiatan Pemasaran Pelaku UMKM Pada Rumah BUMN Purbalingga
}

\author{
Budi Setiyanto ${ }^{1}$, Catur Wisnu Widiantoro ${ }^{2}$, Puput Wahyuningsih ${ }^{3}$, Yuni \\ Eka Achyani ${ }^{4}$ \\ Sistem Informasi \\ Universitas Nusa Mandiri Kampus Kramat Raya Jl. Kramat Raya No.18, RW.7, Kwitang, \\ Kec. Senen, Kota Jakarta Pusat, Daerah Khusus Ibukota Jakarta 10450 \\ Email: yuni.yea@nusamandiri.ac.id, buddisetya@gmail.com, \\ wisnucatur594@gmail.com, Cpuputwhy23@gmail.com
}

\begin{abstract}
Abstrak
Perkembangan dan kemajuan di bidang teknologi dan informasi dapat dimanfaatkan sebagai inovasi untuk mengembangkan bisnis supaya semakin berkembang. Pelaku UMKM di Indonesia telah mencapai 57 juta, dimana sebagian besar merupakan para pelaku usaha mikro. Hal ini menunjukkan potensi UMKM sebagai salah satu penggerak ekonomi Indonesia untuk meningkatkan kemakmuran negeri. Pemanfaatan Aplikasi Marketplace sangatlah tepat mengingat dalam pelaksanaanya banyak sekali kemudahan, salah satunya untuk para pelaku UMKM. Namun masih banyak juga para pelaku UMKM yang masih belum mengetahui tentang apa itu marketplace dan belum bisa memanfaatkan aplikasi marketplace tersebut, dan juga kurangnya kreatifitas yang disebabkan karena keterbatasan pengetahuan sehingga selama ini hanya melakukan jual beli secara langsung dan melalui media sosial dalam kegiatan memasarkan produk UMKM. Pada pelatihan Edukasi Pemanfaatan Aplikasi Marketplace Dalam Menunjang Kegiatan Pemasaran Pelaku UMKM Pada Rumah BUMN Purbalingga akan dikenalkan ap aitu Facebook Marketplace sampai dengan cara posting produk. Dengan adanya edukasi pemanfaatan aplikasi marketplace ini diharapkan dapat membantu para pelaku UMKM di Kabupaten Purbalingga dalam memperluas pemasaran produknya.
\end{abstract}

Kata kunci : Pemasaran, Aplikasi, Marketplace, UMKM

\section{Pendahuluan}

Saat ini pelaku UMKM di Indonesia telah mencapai 57 juta, dimana sebagian besar merupakan para pelaku usaha mikro. BUMN sebagai agent of development telah mengembangkan beberapa insiatif untuk meningkatkan kualitas UMKM, antara lain Bank Mandiri dengan program Wirausaha Muda Mandiri, Bank BNI dengan Kampoeng BNI Nusantara, Bank BRI dengan program Teras BRI dan Telkom Indonesia dengan 2 juta UMKM teregister melalui pogram Kampung UMKM Digital di seluruh Indonesia. Latar belakang didirikannya Rumah BUMN adalah Pertumbuhan pasar global telah menggeser paradigma bisnis nasional, dimana UMKM memegang peranan penting dalam memakmurkan ekonomi negara, baik melalui penciptaan lapangan kerja, mendorong peningkatan kesejahteraan masyarakat, serta menciptakan inovasi baru. Sebagai upaya pemberdayaan ekonomi kerakyatan, khususnya bagi para pelaku usaha mikro kecil dan menengah, Kementrian BUMN bersama perusahaan milik negara membangun Rumah BUMN sebagai rumah bersama untuk berkumpul, belajar dan membina para pelaku UMKM menjadi UMKM Indonesia yang berkualitas.

Usaha Mikro merupakan kegiatan yang dapat memperluas lapangan pekerjaan serta memberikan pelayanan ekonomi secara luas kepada masyarakat dan dapat berperan dalam proses pemerataan dan peningkatan pendapatan masyarakat, mendorong pertumbuhan ekonomi, serta berperan mewujudkan stabilitas nasional. Selain itu, usaha mikro adalah salah satu pilar utama ekonomi nasional yang mendapatkan kesempatan utama, dukungan, perlindungan serta 
pengembangan yang secara luas sebagai wujud pihak yang tegas kepada kelompok usaha ekonomi rakyat, tanpa harus mengabaikan peranan usaha besar dan badan usaha milik pemerintah (Putri $\mathrm{E}$, 2017). Wabah Covid-19 kini menjadi pandemi global setelah diumumkan oleh Badan Kesehatan Dunia dan penyebaran yang begitu cepat menjadikan Covid -19 sebagai topik utama di berbagai negara. Tidak terkecuali di Indonesia jumlah postif terinfeksi Virus Corona atau Covid-19 semakin hari semakin meningkat. Situasi krisis seperti ini tentu berdampak kepada berbagai sektor ekonomi, salahsatunya keberadaan UMKM sangat memerlukan perhatian khusus, karena UMKM penyumbang terbesar PDB dan menjadi andalan dalam penyerapan pengangguran, subtitusi produksi barang konsumsi, mensubtitusi produksi barang konsumsi atau setengah jadi (Awali, 2020).

Dengan kemajuan teknologi dan informasi yang semakin berkembang dapat dimanfaatkan sebagai inovasi untuk mengembangkan bisnis supaya semakin berkembang. Dalam dunia bisnis khususnya kewirausahaan, harus selalu mengikuti tuntutan perkembangan dan kemajuan di bidang teknologi dan informasi. Sehubungan dengan kondisi saat ini, maka pemanfaatan aplikasi marketplace sangatlah tepat mengingat dalam pelaksanaannya banyak sekali kemudahan di dalamnya, salah satunya adalah para pelaku usaha dapat melakukannya dirumah dengan lebih mudah, praktis dan dapat menjangkau konsumen lebih luas. Melakukan promosi atau pemasaran melalui aplikasi marketplace terbukti mampu meningkatkan penghasilan dan usaha menjadi semakin berkembang dari waktu ke waktu. Namun masih banyak diantara para pelaku UMKM yang masih belum mengetahui dan belum bisa memanfaatkan aplikasi marketplace tersebut. Salah satunya di Rumah BUMN Kabupaten Purbalingga, oleh karena itu kami melakukan pengabdian masyarakat dengan judul "Edukasi Pemanfaatan Aplikasi Marketplace Dalam Menunjang Kegiatan Pemasaran Pelaku UMKM Pada Rumah BUMN Purbalingga".

\subsection{Tujuan Kegiatan}

Tujuan kegiatan ini untuk untuk meningkatkan pengetahuan, keterampilan dan pertumbuhan omset para pelaku UMKM di Rumah BUMN Purbalingga.

\subsection{Manfaat Kegiatan}

Manfaat kegiatan ini diharapkan kepada peserta untuk menguasai pemanfaatan Aplikasi Marketplace yang saat ini banyak digunakan oleh pelaku usaha untuk memudahkan proses pemasaran dan penjualan dengan jangkauan pasar yang lebih luas, sehingga diharapkan dapat menambah angka penjualan menjadi lebih baik.

\subsection{Luaran Pengabdian Masyarakat}

Target Luaran dalam kegiatan pengabdian kepada masyarakat ini, yaitu:

a) Para pelaku UMKM di Rumah BUMN Purbalingga mengenal Aplikasi Marketplace.

b) Para pelaku UMKM di Rumah BUMN Purbalingga mendapatkan pengetahuan bagaimana cara melakukan kegiatan pemasaran di Aplikasi Marketplace.

c) Buku Bahan Ajar.

d) Artikel Ilmiah.

\section{Realisasi Kegiatan}

\subsection{Bentuk Kegiatan, Jadwal dan Tempat Kegiatan \\ a. Metode Pelaksanaan Kegiatan}

Kegiatan pelatihan untuk pelaku UMKM pada Rumah BUMN Purbalingga mengangkat tema Edukasi Pemanfaatan Aplikasi Marketplace Dalam Menujang Kegiatan Pemasaran. Metode dalam pelatihan ini adalah ceramah dan diskusi. Dengan metode ceramah peserta diperkenalkan dengan pengertian facebook Marketplace, fitur-fitur facebook Marketplace, cara akses facebook Marketplace, hal yang harus dipertimbangkan sebelum jualan di facebook Marketplace, cara posting dan tips jualan laris di facebook Marketplace. Metode diskusi dilaksanakan dengan memberikan kesempatan kepada peserta untuk bertanya dan memberikan tanggapan dari bahan pelatihan tersebut. Pelatihan ini dilaksanakan selama 1 (satu) hari dengan durasi 3 jam. Dalam kegiatan pelatihan setiap peserta mendapatkan modul yang dishare melalui grup whatsapp peserta kegiatan. 


\section{b. Waktu Efektif Pelaksanaan Kegiatan}

Kegiatan Pelatihan Edukasi Pemanfaatan Aplikasi Marketplace Dalam Menujang Kegiatan Pemasaran ini sebagai Pelaksanaan kegiatan Pengabdian Kepada Masyarakat telah dilaksanakan pada Tanggal 11 November 2021 dengan tentatif kegiatan sebagai berikut:

Tabel 1. Jadwal Pelaksanaan

\begin{tabular}{|c|c|c|c|c|c|}
\hline \multirow{2}{*}{ No } & \multirow{2}{*}{ Kegiatan } & \multicolumn{4}{|c|}{ Jadwal Kegiatan } \\
\hline & & 09.00-09.15 & 09.15-10.15 & $10.15-10.45$ & $10.45-12.00$ \\
\hline 1 & Perkenalan dan pengantar materi presentasi & & & & \\
\hline 2 & $\begin{array}{l}\text { Pengantar Materi 1: pengertian facebook } \\
\text { Marketplace, fitur-fitur facebook Marketplace, cara } \\
\text { akses facebook Marketplace, hal yang harus } \\
\text { dipertimbangkan sebelum jualan di facebook } \\
\text { Marketplace }\end{array}$ & & & & \\
\hline 3 & $\begin{array}{l}\text { Lanjutan Materi: cara posting dan tips jualan laris di } \\
\text { facebook Marketplace }\end{array}$ & & & & \\
\hline 4 & Latihan: Posting Produk di Facebook Marketplace & & & & \\
\hline
\end{tabular}

\section{c. Tempat Kegiatan}

Kegiatan ini dilakukan di Rumah BUMN Purbalingga, Jl. Mayjend Sungkono KM. 05, Blater RT 001 RW 006, Kecamatan Kalimanah, Kabupaten Purbalingga. Yang dilaksanakan pada hari Kamis, 11 November 2021 dimulai dari pukul 09.00 WIB sampai dengan pukul 11.00 WIB.

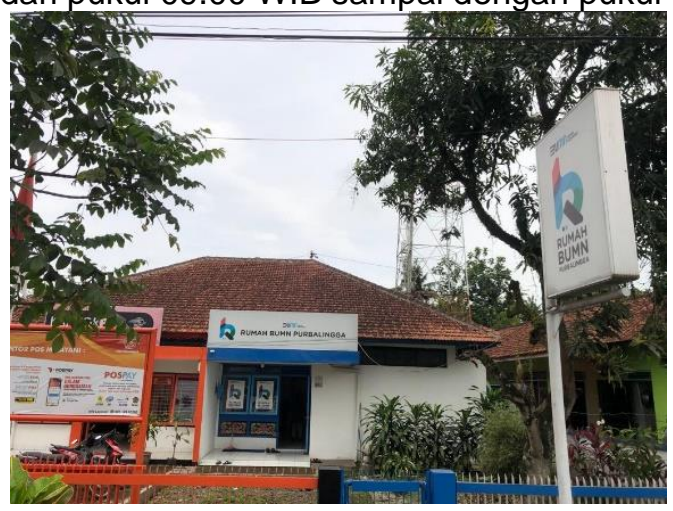

Gambar 1. Lokasi Kegiatan

\subsection{TIM Pelaksana Pengabdian dan TUPOKSI serta (Jam dan hari)}

a. Susunan TIM Pengabdian

\begin{tabular}{|l|l|l|l|}
\hline No & Peran dalam TIM & Tanggung jawab dalam TIM & Dosen/Mahasiswa \\
\hline 1 & Yuni Eka Achyani & Penanggung Jawab & Dosen \\
\hline 2 & Budi Setiyanto & Ketua Pengabdi & Mahasiswa \\
\hline 3 & Catur Wisnu W & Anggota Pengabdi & Mahasiswa \\
\hline 4 & Puput Wahyuingsih & Anggota Pengabdi & Mahasiswa \\
\hline
\end{tabular}

b. Tugas Pokok serta Peran setiap TIM Pengabdian

\begin{tabular}{|c|c|c|c|c|}
\hline No & Nama Pekerjaan & Program & Volume & Pemateri \\
\hline \multicolumn{5}{|c|}{ Kamis, 11 November 2021} \\
\hline 1. & $\begin{array}{l}\text { Facebook } \\
\text { Marketplace }\end{array}$ & $\begin{array}{l}\text { - Pengertian Facebook Marketplace } \\
\text { - } \text { Citur-fitur Facebook Marketplace } \\
\text { - Hal yang harus dipertimbangkan } \\
\text { sebelum jualan di Facebook } \\
\text { Marketplace }\end{array}$ & $\begin{array}{c}09.15- \\
10.15 \text { WIB }\end{array}$ & Budi Setiyanto \\
\hline 2. & $\begin{array}{l}\text { Lanjutan Facebook } \\
\text { Marketplace }\end{array}$ & $\begin{array}{l}\text { - Cara Posting Produk di Facebook } \\
\text { Marketplace } \\
\text { - Tips Jualan Laris di Facebook } \\
\text { Marketplace }\end{array}$ & $\begin{array}{r}10.15- \\
10.45 \text { WIB }\end{array}$ & Budi Setiyanto \\
\hline
\end{tabular}

Edukasi Pemanfaatan Aplikasi Marketplace Dalam Menunjang Kegiatan Pemasaran Pelaku UMKM Pada Rumah 


\begin{tabular}{|c|c|c|c|c|}
\hline No & Nama Pekerjaan & Program & Volume & Pemateri \\
\hline 3. & Praktek & $\begin{array}{l}\text { - Posting Produk di Facebook } \\
\text { Marketplace }\end{array}$ & $\begin{array}{c}10.45-12.00 \\
\text { WIB }\end{array}$ & $\begin{array}{l}\text { Budi } \\
\text { Setiyanto } \\
\text { Catur Wisnu } \\
\text { W } \\
\text { Puput } \\
\text { Wahyuningsi } \\
\text { h }\end{array}$ \\
\hline
\end{tabular}

\subsection{Ringkasan/Garis-garis besar Materi}

\section{a. Aplikasi Pemasaran Facebook Marketplace}

Menurut Hengky (2010), "aplikasi adalah satu unit perangkat lunak yang dibuat untuk melayani kebutuhan akan beberapa aktivitas seperti sistem perniagaan, game, pelayanan masyarakat, periklanan atau semuua proses yang hampir dilakukan manusia" (Sari, 2017). Menurut Jogiyanto HM (dalam suhartini (2017), aplikasi merupakan penerapan, menyimpan sesuatu hal, data, permasalahan, pekerjaan ke dalam suatu sarana atau media yang dapat digunakan untuk diterapkan menjadi sebuah bentuk yang baru (Siregar, H. F., Siregar, Y. H., \& Melani, 2018).

Banyak perubahaan kritis yang terjadi dalam pasar konsumen dan pasar bisnis selama dasawarsa terakhir. Pasar konsumen sering ditandai oleh populasi yang semakin tua, jumlah pekerja wanita yang meningkat, pernikahan yang ditunda, perceraian yang lebih banyak, dan keluarga yang lebih kecil, munculnya kelompok dan kebutuhan pelanggan etnis yang berbedabeda, dan menjamurnya beragam gaya hidup konsumen. Pasar bisnis juga menuntut produk dengan kualitas yang lebih tinggi, pengiriman yang lebih cepat, pelayanan yang lebih baik, dan harga yang lebih rendah. Perusahaan bisnis perlu mempercepat proses pengembangan produk mereka karena siklus hidup produk yang lebih singkat. Mereka juga perlu mencari cara yang lebih baik untuk menyalurkan dan mempromosikan produk mereka dengan biaya yang lebih rendah. (Philip Kotler,1997;8) (Sahla, 2019).

Di Indonesia jumlah pengguna facebook tahun 2020 berjumlah 130 juta jiwa dengan jenis kelamin pria $44,5 \%$ serta wanita $55,6 \%$ dari jumlah pengguna (Riyanto, 2020). Melihat fakta yang terjadi pada masyarakat tersebut maka aplikasi media sosial Facebook meluncurkan fitur digital marketingnya yaitu dengan kehadiran marketplace. Facebook marketplace ini merupakan pengembangan dari Facebook Group dan dibuat karena banyaknya aktivitas jual beli dalam jejaring media sosial tersebut, hingga saat ini tercatat lebih dari 450 juta orang yang melakukan nya dalam sebulan (Ku, 2016). Fitur facebook marketplace ini merupakan bentuk dari sebuah pasar online yang mewadahi berbagai kegiatan jual beli para penggunanya, dan pada saat membukanya para pengguna akan disambut dengan rangkaian foto barang dagangan yang lokasinya paling dekat (Widiartanto, 2016). Marketplace yang disediakan oleh facebook memiliki segementasi pasar yang dapat diterapkan secara luas untuk aktivitas ekonomi business to business, business to costumer serta costumer to costumer (Chef, 2020) (Simatupang et al., 2021).

1) Fitur-fitur Facebook Marketplace

a) Fitur pencarian barang

Fitur ini memungkinkan setiap pengguna untuk mencari dan memfilter daftar barang yang dapat kita beli dari sebuah komunitas tertentu. Kemampuan ini dapat dikembangkan berkat adanya teknologi "Text Analysis Al" yang dikombinasikan dengan Facebook Page tertentu yang disukai oleh pengguna. Dari situlah nanti, akan muncul serangkaian daftar berdasarkan relevansi produk yang kemungkinan disukai oleh pengguna. Bagi mereka yang ingin membeli, ada beberapa pilihan instanttext yang bisa digunakan untuk membuka percakapan transaksi. Teks tersebut diantaranya yakni, "Apakah barang tersebut masih tersedia?" serta "Bagaimanakah kondisi dari barang tersebut?". Dengan begitu, proses jual beli personal semacam ini bisa dilakukan dengan lebih cepat.

b) Fitur menjual barang. 
Tanpa perlu membuat halaman khusus yang berisi daftar barang yang anda miliki, kita tinggal mengupload foto dari produk tersebut kemudian memberikan deskripsi serta harga yang ditawarkan. Dari situ pengguna tinggal memasukkan pada daftar atau listing produk yang telah disediakan.

c) Fitur Pencarian sekitar

Fitur ketiga yang juga cukup menarik yaitu melakukan pencarian di kawasan sekitar. Nantinya dengan Facebook Marketplace, pengguna bisa mencari produk-produk yang ditawarkan oleh pengguna yang ada di sekitar tempat tinggal kita. Keuntungan dari fitur ini yaitu, kita bisa lebih cepat untuk mendatangi si penjual jika memang tertari k dengan produk yang dijual. Selain itu, fitur ini juga mendorong peningkatan penjualan secara lokal termasuk yang di tawarkan oleh UKM. Dalam Fitur Facebook Marketplace, sifat internet yang global akan dikerucutkan sesuai dengan tempat tinggal maupun komunitas pengguna Facebook. $\mathrm{Hal}$ ini pun sesuai dengan perubahan algoritma yang telah dilakukan oleh Facebook, ini sesuai dengan keterangan yang kami dapat dari Newsroom Facebook.

2) Cara Akses Facebook Marketplace

a) Klik icon Facebook pada tampilan layer utama handphone anda.

b) Pilih tab dengan gambar toko/kios

3) Hal yang Harus Dipertimbangkan Sebelum Jualan di Facebook Marketplace

a) Pengiriman

b) Akan ada banyak komunikasi / pesan dari pembeli

4) Keuntungan Berjualan di Facebook Marketplace

a) Jumlah Teman Tidak Terbatas

b) Mudah dan Praktis untuk Berbagi Informasi Produk

c) Bisa Beriklan Sesuai Target Pembeli

d) Kualitas Gambar yang Diposting Tidak Berubah

e) Memiliki Fitur Ulasan Produk

f) Bisa Digunakan untuk Mengunggah Video Panjang

g) Mudah Digunakan untuk Memantau dan Menganalisis Penjualan

b. Praktek Facebook Marketplace

1) Cara Posting Produk di Facebook Marketplace.

a) Klik menu utama Facebook di kanan atas sehingga akan muncul gambar dibawah ini.

b) Setelah berada di halaman Marketplace, klik "jual" atau "sell".

c) Secara default, Facebook hanya akan menampilkan 4 pilihan kategori saja. Pilih

"item" untuk melanjutkan.

d) Pilihlah kategori sesuai dengan barang yang akan Anda jual. Jika tidak ada, pilih "lainlain".

e) Upload foto produk dan isi semua kolom dengan lengkap.

f) Lanjutkan dengan melengkapi harga, deskripsi, dan semua kolom yang ada di halaman

tersebut, kemudian klik tombol "selanjutnya" atau "next" yang berada di sebelah kanan atas.

g) Setelah itu Anda akan dibawa ke halaman dengan beberapa pilihan posting. Pilih grup

yang akan anda tuju untuk posting produk Anda, atau kosongi jika Anda hanya akan menampilkan produk di Marketplace saja.

h) Untuk melihat postingan Anda silakan kembali ke halaman Marketplace kemudian klik

"gambar profil" di sebelah kiri atas.

i) Kemudian klik tombol "penawaran Anda".

2) Tips Jualan Laris di Facebook Marketplace 
Untuk memenangkan persaingan di dalam Facebook Marketplace bukanlah hal yang susah bagi yang sudah menguasai tehniknya. Tetapi hal ini butuh konsistensi yang tinggi dan bukanlah sesuatu yang bisa didapat secara instan.

a) Posting Minimal 10 Kali Sehari.

b) Upload Gambar Cover Yang Berbeda Di Setiap Posting

c) Judul Harus Beda, Keterangan Produk Boleh Sama

d) Tentukan Lokasi Yang Berbeda Di Setiap Posting

e) Fokus Hanya Di Marketplace Dan Hindari Posting Ke Grup Facebook

f) Pilih Variasi Kategori Yang Berbeda Di Setiap Posting

g) Sertakan Nomer Whatsapp Di Setiap Keterangan Produk

h) Fast Respon Inbox Messenger

i) Konsisten

\subsection{Masyarakat Sasaran}

Sasaran kegiatan ini adalah para pelaku UMKM di Kabupaten Purbalingga yang berada dibawah binaan Rumah BUMN Purbalingga dengan jumlah 20 peserta. Penetapan sasaran ini merupakan suatu upaya untuk meningkatkan pengetahuan, keterampilan dan pertumbuhan omset para pelaku UMKM di Rumah BUMN Purbalingga. Lebih jauh dari itu harapannya adalah para peserta bisa menularka ilmu yang diperoleh kepada para pelaku UMKM lain yang berada di Kabupaten Purbalingga dan sekitarnya.

\section{Tinjauan Hasil Yang Dicapai}

Kegiatan pelatihan Edukasi Pemanfaatan Aplikasi Marketplace Dalam Menujang Kegiatan Pemasaran Pelaku UMKM Pada Rumah BUMN Purbalingga telah dilaksanakan dengan baik. Berdasarkan jumlah peserta yang hadir sebanyak 16 orang peserta dari berbagai jenis UMKM menunjukan minat yang tinggi untuk mengikuti kegiatan pelatihan ini. Dengan kondisi saat ini yang mengharuskan para pelaku UMKM untuk mengikuti perkembangan teknologi dan informasi didalam melakukan kegiatan pemasaran produk salah satunya melalui Aplikasi Marketplace. Berdasarkan pelatihan dan uji coba praktek yang diberikan kepada peserta setelah mengikuti pelatihan dapat disimpulkan bahwa peserta sudah mampu melaukukan kegiatan posting produk pada Facebook Marketplace dan mengelola produk-produk yang sudah terposting. Sebagai umpan balik dari kegiatan ini peserta dapat terus mempelajari bagaimana cara mengoptimalkan fasilitas-fasilitas pada Aplikasi Marketplace agar bisa menjangkau pasar yang lebih luas dan mampu meningkatkan omset penjualan.

\section{Daftar Pustaka}

Awali, H. (2020). Urgensi Pemanfaatan E-Marketing Pada Keberlangsungan Umkm Di Kota Pekalongan Di Tengah Dampak Covid-19. BALANCA : Jurnal Ekonomi Dan Bisnis Islam, 2(1), 1-14. https://doi.org/10.35905/balanca.v2i1.1342

Putri E, H. (2017). Efektivitas Pelaksanaan Program Pengembangan Usaha Mikro Kecil Dan Menengah (UMKM) Di Kota Samarinda ( Studi Pada Dinas Koperasi Dan UMKM Kota Samarinda ). E-Journal Administrasi Negara, 5(1), 5431-5445.

Sahla, H. (2019). Konsep Pemasaran dalam Perspektif Ekonomi Islam. Jurnal Pionir LPPM Universitas Asahan, 5(2), 57-61.

Sari, Y. P. (2017). Rancang Bangun Aplikasi Penjualan Dan Persediaan Obat Pada Apotek Merben Di Kota Prabumulih. Jurnal Sistem Informasi Dan Komputerisasi Akuntansi (Jsk), 1(1), 81-88.

Simatupang, S., Efendi, E., \& Putri, D. E. (2021). Facebook Marketplace Serta Pengaruhnya Terhadap Minat Beli. Jurnal Ekbis, 22(1), 28. https://doi.org/10.30736/je.v22i1.695

Siregar, H. F., Siregar, Y. H., \& Melani, M. (2018). (2018). Perancangan Aplikasi Komik Hadist Berbasis Multimedia. JurTI (Jurnal Teknologi Informasi), 2(2), 113-121. JurTI (Jurnal Teknologi Informasi), 2(2), 113-121. http://www.jurnal.una.ac.id/index.php/jurti/article/view/425 


\section{Daftar Hadir}

Daftar Hadir Peserta kegiatan ini adalah sebagai berikut :

\section{DAFTAR HADIR PESERTA}

KEGIATAN PENGABDIAN KEPADA MASYARAKAT

EDUKASI PEMANFAATAN APUIKASI MARKETPLACE DALAM MENUNJANG KEGIATAN PEMASARAN

PELAKU UMKM PADA RUMAH BUMN PURBALINGGA

KAMIS, 11 NOVEMBER 2021

\begin{tabular}{|c|c|c|c|c|c|}
\hline No & NAMA & UМКм & NO HANDPHONE & & TTD \\
\hline 1 & Aad Purwanto & Alzavera & $0850 \mathrm{~g} 0147725$ & $1 / 1 / 2$ & \\
\hline 2 & Faja Dwis & Madu hulan & 085741602354 & & $2 \circlearrowleft$ \\
\hline 3 & Miswanto & Pempach Instan "Titithenvi & $\$ 8224112423$ & $39=$ & \\
\hline 4 & DIDIK $S$ & Pakuneen 1 & 085640002363 & & 4 (1) \\
\hline 5 & Solched: Aluned H. & Mrelset & 085647993431 & & \\
\hline 6 & SAIPUL MUNIF & BuBur Sumsuma CAMDLL & 085738713569 & & \\
\hline 7 & Priyanto & Pakaian & 085700392522 & $7 \%$ & \\
\hline 8 & Rizgi & Poxkanimode & $0022-2142-1623$ & & \\
\hline 9 & Tih Siwant & Mrebet & $0852 \quad 91333514$ & As & \\
\hline 10 & Lena Wiqiarti & MUREBEI & 081315893191 & & 10,921 \\
\hline 11 & Fitria & babakan & 081378361331 & $11 \mathcal{L}$ & \\
\hline 12 & Ratih P & kutasori & 088808944440 & & 12 appe4 \\
\hline 13 & $\mid r m a \cdot y$ & Tahal, karangreja & 085791914081 & $13 \gamma \mathrm{m}$ & \\
\hline 14 & Arum Seiphia. R & Bohotsari(patalan) & 085701169449 & & \\
\hline 15 & Rini Subekt & Matenogyeng if of 10 / skinmode & 083822822672 & 15 tere & \\
\hline 16 & Nuha Shofiya & Skinmode & 085799831823 & & 16 fl. - \\
\hline 17 & & & & 17 & \\
\hline 18 & & & & & 18 \\
\hline 19 & & - & & 19 & \\
\hline 20 & & & & & 20 \\
\hline
\end{tabular}




\section{Surat Keterangan}

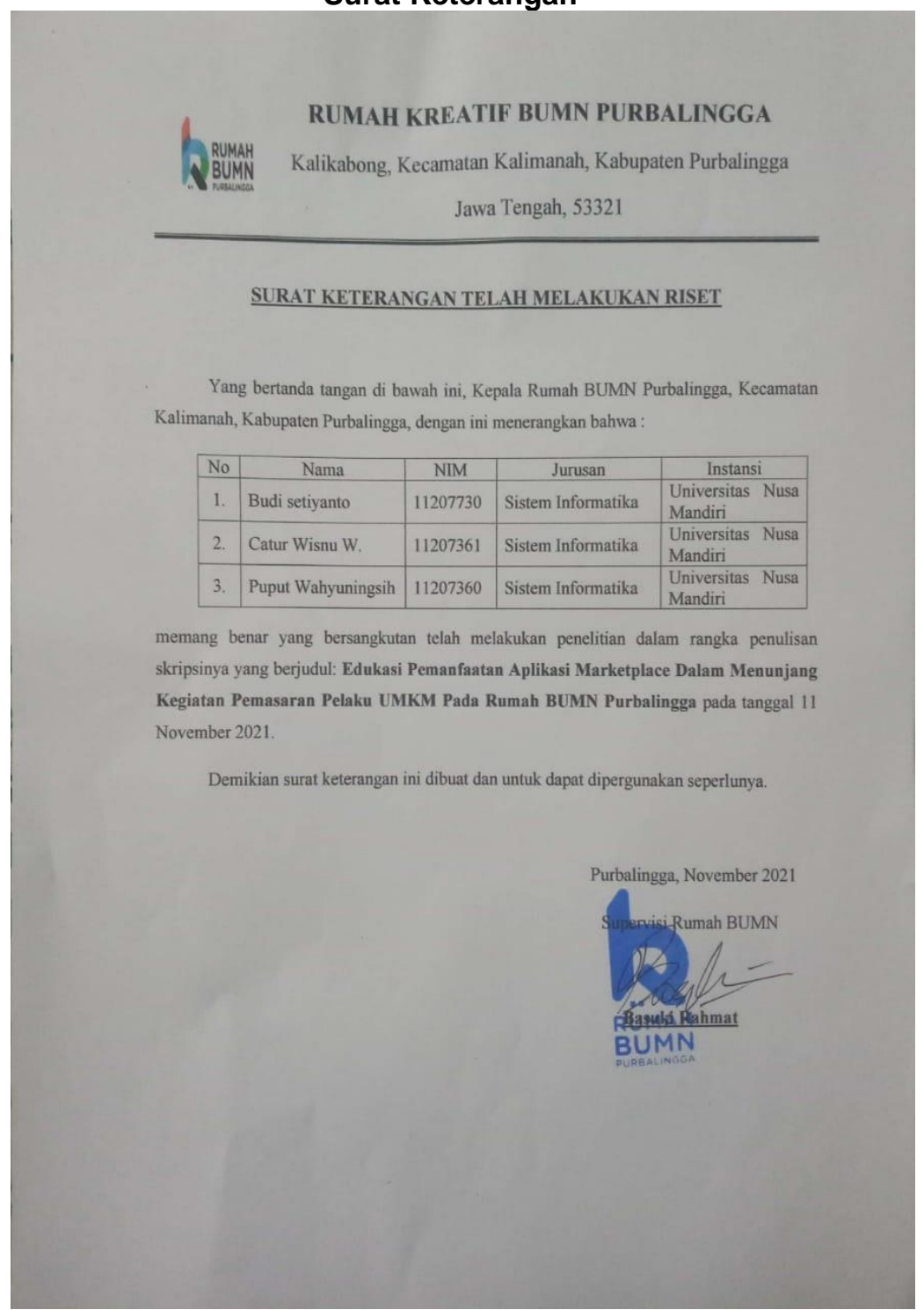

\section{Foto Kegiatan}

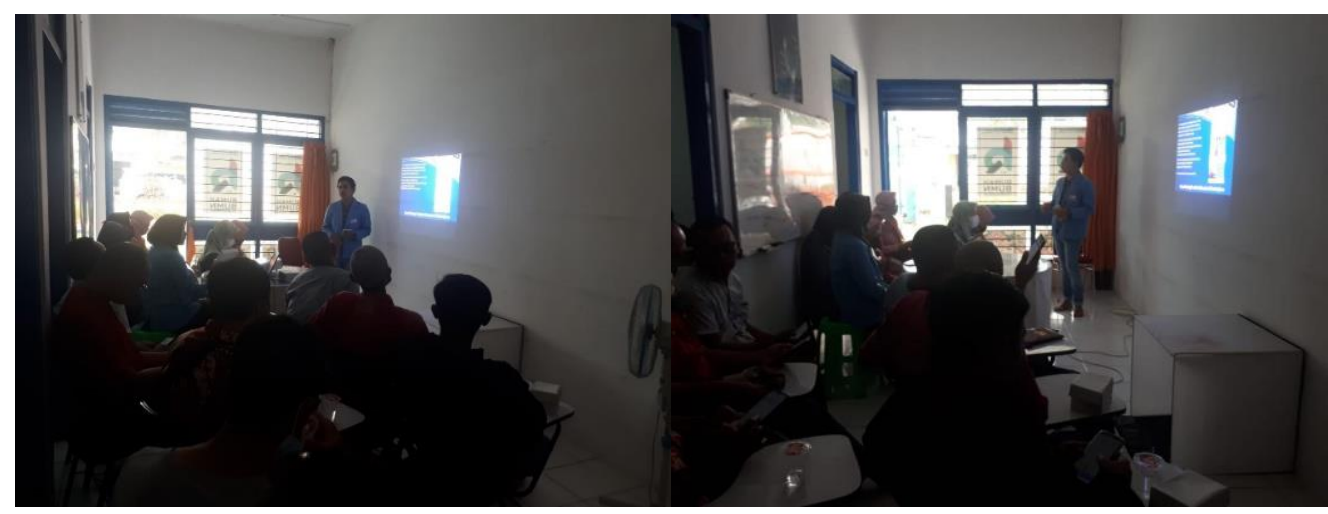



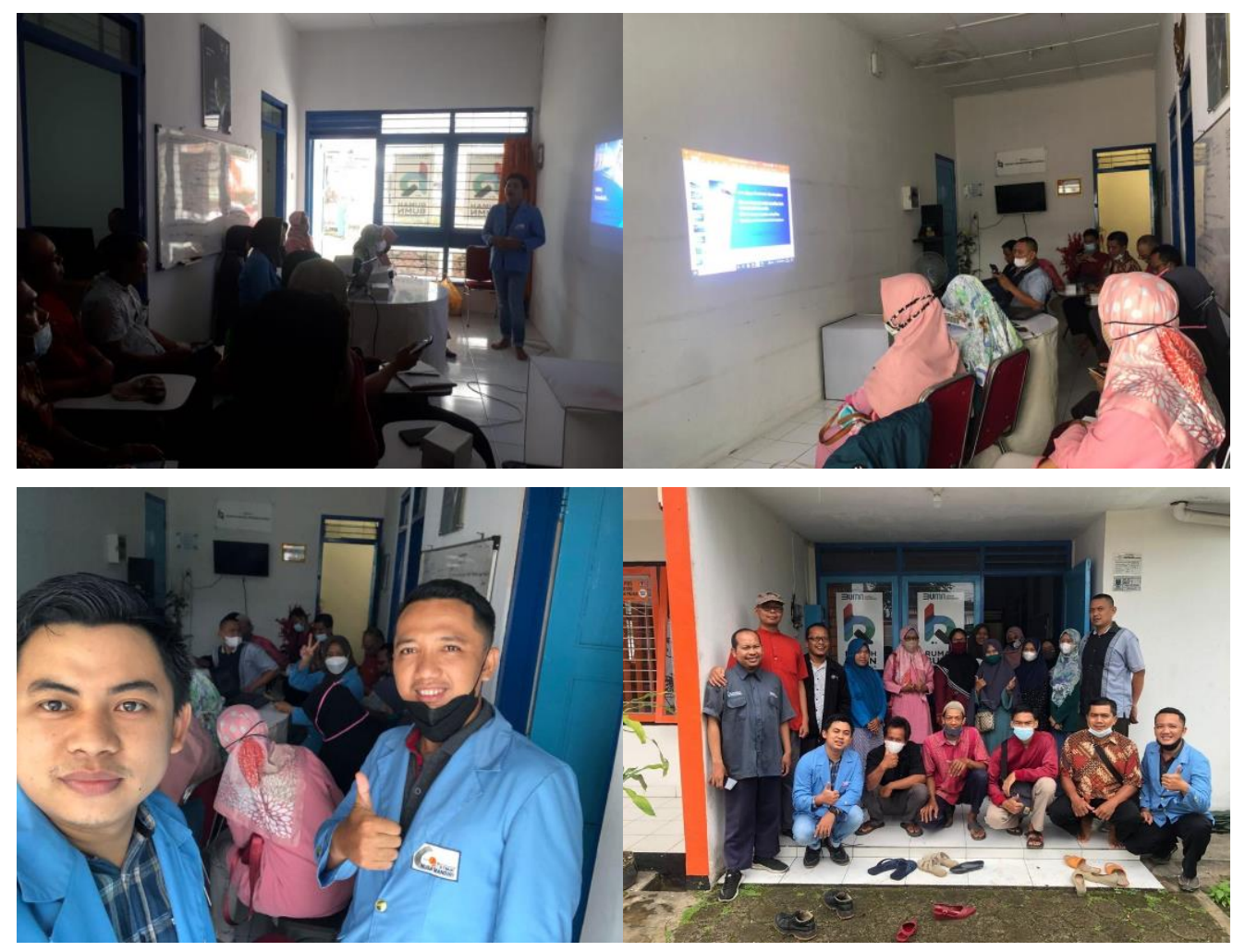